\title{
TOWARDS A FLUID AND MULTISCALAR GOVERNANCE OF EXTRACTIVE RESOURCES IN AFRICA ${ }^{1}$
}

\author{
Cristina D'Alessandro*
}

\begin{abstract}
Political geographies of oil investigate extractive value chains with an emphasis on governance and scales, analysing the role that territories and especially spatial networks play in these dynamics. While underlining the limits and gaps of territorial governance, as it is nowadays theorized and used in the academic literature, extractive resources, particularly in developing contexts, call for fluid networks, and multiscalar governance; more flexible and adapted to changing contexts. This approach leads to networked justice, as a consequent adaptation of spatial justice to these specific situations. This article points out, for instance, the geopolitics of pipelines in Africa and its critical role in transforming the continent, despite its related challenges and conflicts. It advocates a better governance of extractive resources in Africa. Scholars have a role to play in this process, helping to analyse critical phenomena and sensitive dynamics, as well as provide sound policy recommendations.
\end{abstract}

Keywords: Extractive resources, sub-Saharan Africa, territorial governance, political geography, justice.

DOI: https://dx.doi.org/10.4314/jsdlp.v8i1.14

\section{INTRODUCTION}

In 1976, the French geographer Armand Frémont published La region, espace vécu (the region, a lived space). This well-known book became the symbol of a renewal and change of French regional geography, calling for more flexible regions not uniquely defined by administrative borders. Among the various examples presented in the book, Frémont

Senior Fellow, Centre on Governance, University of Ottawa, Canada.

1 This paper is part of the Qatar Foundation's National Priorities Research Programme - NPRP 6-1272-5-160. 
recalls that Jean Gallais, a former French geographer, had been a precursor studying the functional region of the internal delta of the Niger River in Mali, showing how this space was a region created by the economic activities of local populations. Using an unprecedented geographical approach, compared to the regional spaces analysed by contemporary French geographers, Gallais illustrates how human geography may give interesting insights on the exploitation of natural resources, studying the role of spaces, networks, and places in these dynamics. ${ }^{2}$

From the 1940s to 1950s, the internal delta of the Niger River was a mobile region, with changing size and shape (even from one season to the following one), depending on the activities (fishing, cattle raising, and agriculture) exploiting local resources (the water of the river and the fertile land left by the river after its level had gone down after the rainy season) at a given time. These traditional socio-economic activities and livelihood strategies of the region became more complex over time, as new resources were discovered and exploited (such as hydraulic energy). Furthermore, the use of coveted and limited resources (like land), the need to adapt to constraints (due to climate change and hydraulic infrastructures, like the dam built in Mopti), and environmental protection policies produce difficulties, conflicts, and tensions. ${ }^{3}$ The logics regulating the way societies function in their space, exploiting the resources locally available have changed in the region as new activities (like the unsuccessful irrigated rice production in the past $^{4}$ and tourism in recent times) have been added. Activities, like cattle-raising and agriculture, produce overlapping and intertwining spaces, while the commercialization of fish creates multiscalar networks, where key places like the river or urban centres are crucial centres.

2 For the definition of these concepts in human geography: J. Lévy and M. Lussault, Dictionnaire de la géographie et de l'espace des societies (Belin, 2013).

3 Marie-Laure De Noray, "Delta intérieur du fleuve Niger au Mali - quand la crue fait la loi: l'organisation humaine et le partage des ressources dans une zone inondable à fort contraste" December 2003 Vertigo 4(3) < https://vertigo. revues.org/3796> accessed 24 January 2016.

4 This is the sadly famous French project known through the name of the institution managing it: The Office du Niger going back to the 1920s (Vittorio Morabito, 'LOffice du Niger au Mali, d'hier à aujourd'hui' (1977), Journal des Africanistes 47(1), 53-82. 
Gallais' (1967) analysis of this natural resource rich Malian region ${ }^{5}$ shows that in African contexts the exploitation of natural resources has always created fluid, networked, and mobile regions, spaces without borders, with changing size and shape. Inspired by Gallais' precursor vision, in the contemporary global world, resource extraction and transformation produce mobile spaces, ${ }^{6}$ open by nature, where movement (of products, individuals, and powers) is at the core. Consequently, places are intersections, where different realities and interests come together. Territories, intended as spaces with fixed borders, are consequently bypassed by these multiscalar spatial logics of mobility and fluidity.

How geographers define regions and translate them into reality by planning and policy is often similar to fixed territories, explaining its intrinsic limitations regarding natural resource exploitation in a global world. The history of French geography and how regions were studied in the past also give insights into regional integration, as encouraged by African states and international institutions and organizations in contemporary Africa. Regions studied by the so-called possibilist geography of Paul Vidal de la Blache and his followers ${ }^{7}$ was a territorial division determined once and for all with precise and well-defined borders, often linked to an administrative division, dictated by historical and social reasons and/or justifications related to physical factors (a river, a mountain, etc.), impressing a strong territorial fracture. The African Regional Economic Communities (RECs) are nowadays macroterritories, made up of the national territories of their member states. The limitations of these territories come from their rigidity (their fixed borders) and their level ${ }^{8}$ (too large areas), making territorial governance more challenging. ${ }^{9}$ Scale, in geography, refers to the changing size of a

5 Jean Gallais, Le delta intérieur du Niger. Etudes de géographie régionale (Institut Français d'Afrique Noire 1967).

6 Denis Retaillé, "De l'espace nomade à l'espace mobile en passant par l'espace du contrat" (2012) Harchives ouvertes < https://hal.archives-ouvertes.fr/halshs00679163/document> accessed 24 January 2016.

7 Vincent Berdoulay, La formation de l'Ecole française de géographie (Editions du C.T.H.S. 1995); Paul Claval, Histoire de la géographie (PUF, 2011).

8 For a definition of the concept of scale in human geography and for an overview on the debate related to it: J. Lévy and M. Lussault, Dictionnaire de la géographie et de l'espace des societies (Belin, 2013).

9 To this has to be added a further constraint coming from the fact that African states are resistant to give up to the RECs the power to control their territories and their transformation over time. 
phenomenon or space and the transformation of its features.

This rigid possibilist definition of the region remained dominant and fundamentally unchanged in French geography until the end of the 1950s. Only in the 1960s-1970s, with the advent of what has been named the new geography, and its concept of space, did the region become a less homogeneous area in which the geographer could identify coherent spatial units linked by interrelated processes. This theoretical development allowed geographers to point out and theorize the fundamental role of urban centres in the structuring of regional spaces. ${ }^{10}$ This opened the way to future resource regionalisms, particularly relevant in African contexts, where regions are mobile spaces, changing and fluctuating with the resources available and exploited: ${ }^{11}$ they are economic and ecological regions created by a specific resource.

They are also networked realities, such as regional electricity grids or transboundary rivers (as exemplified by the description of the Malian Niger River Delta previously mentioned). "Resource regionalisms may be one of the keys to improved economic development, through increased foreign direct investment, improved governance, and more reliable access to energy". ${ }^{12}$

In agreement with Deese on the need to encompass rigid and large regional integration processes towards sector-specific regionalisms among which the ones related to natural resources are particularly key in Africa, this article emphasizes the need for multiscalar, fluid, and networked governance mechanisms to better manage natural resource exploitation, especially for networked resources, such as the extractives. ${ }^{13}$ This mechanism and vision calls for harmonized policies at the various levels (local, micro-regional, nation, macro-regional, continental, and global), thus creating a multiscalar governance system. As spaces or regions are fluid and mobile, depending on the resources present and exploited over time, governance must also be fluid, adapting policies and actions to the resources extracted.

10 Etienne Juillard, “La région: essai de definition" (1962) Annales de Géographie 71(387), 483-499.

11 David E. Deese (ed), Handbook of the International Political Economy of Trade (Edward Elgar Publishing, 2014).

12 Ibid, p. 289.

13 Cristina D'Alessandro, "From Regional Integration to Regionalism in Africa: Building Capacities for the Post-MDGs Agenda", in George Kararach, Hany Besada and Timothy Shaw (eds.), Development in Africa. Refocusing the Lens after the Millennium Development Goals (Policy Press, 2015), 261-292. 
These views on multiscalar, networked, and fluid governance are particularly helpful in developing contexts, such as in African countries, where gaps in institutional capacities, political instability, risks, conflictual situations, and social inequalities make the governance of natural resources particularly difficult, but at the same time strategic, because success and failures in this domain have key consequences at various levels (from local conflicts to the global consequences of the market pressures on oil).

The impact of a more or less efficient management of natural resources may not be limited to the political and economic spheres. Natural resource governance produces sizeable effects on the quality of life of individuals and local societies in both negative and positive ways, whether through accumulated revenues (better incomes, changing lifestyles, new patterns of consumption, etc.) or environmental impacts (pollution, risks, health concerns, etc.). Exploitation of natural resources demands effective governance to protect and accompany societies in their transformation due to resource extraction. The discovery of a new natural resource in a given place or the exploitation made possible by new technologies available at certain time change the life of the local communities living nearby, even if only through the impact on higher prices paid by consumers to buy food or ordinary products or by the pollution that their exploitation may engender.

Inspired by some geographical concepts, theories and approaches, as well by African examples, this article explores alternative fluid, networked, and multiscalar governance regimes ${ }^{14}$ in African contexts. Governance structures and capacities in fact greatly vary with the scale of action (from the local community level to the continental and even global scale) and the resource (oil governance is much different from land governance, as their geographical patterns are diversified). After a presentation of various geographies of oil at different scales, the article develops an analysis of its fluid, multiscalar, and networked governance. This governance is a multifaceted and complex mechanism of interaction and management in which numerous stakeholders are

14 A governance regime defines the quality and level of functioning of political institutions. Nevertheless it has been demonstrated that it is related to the economy, especially to the capacity to control corruption and sustain growth through effective natural resource extraction (Toke Aidt, Jayasri Dutta and Vania Sena, "Governance regimes, corruption, and growth: theory and evidence" (2008), Journal of Comparative Economics, 36, 195-220). 
involved and with a fundamental environmental dimension. It cannot be reduced to state agreements and to the role of oil companies in oil extraction: it encompasses the national level, creating mobile and networked spaces. This oil governance also calls for a networked fluid, networked, and multiscalar spatial justice, taking into account the role and specific characteristics of these spaces to set in place management mechanisms protecting the environment as well as the interests of the various stakeholders involved, especially the most vulnerable among them.

After this introduction, this article defines and questions in section 2 the political geography of oil. Section 3 presents territorial governance, underlining its unsatisfactory features for extractive resources. Section 4 consequently investigates some characteristics of the fluid, networked, and multiscalar governance of oil. Section 5 introduces the concept of spatial justice into this approach, calling instead for networked justice. The article ends by presenting the advantages offered by a better governance framework of extractives in Africa. Governance of extractives indeed has a crucial role across the continent, given their widespread and unique geographical features.

\section{POLITICAL GEOGRAPHIES OF OIL AND THEIR SCALES}

Among contemporary natural resources, oil has certainly a peculiar place for its key overriding socio-economic role, but also for the complexity of the consequences that it produces at various levels. ${ }^{15}$ Michael Watts has underlined that the liquid and greasy status of oil is not insignificant to understand its related dynamics. ${ }^{16}$ Oil is a hidden, inflammable, and explosive liquid: it is by nature not very propitious to be domesticated and transformed. For instance, some reserves in deep water exploited in Morocco, Egypt and Angola are located 10,660m below sea level, requiring very sophisticated technologies ${ }^{17}$ to

15 Jean Pierre Favennec and Philippe Copinschi, "Les nouveaux enjeux pétroliers en Afrique" (2003) Politique africaine, 1(89), 127-148.

16 Michael Watts, "Petro-violence: Community, Extraction, and Political Ecology of a Mythic Commodity" in Nancy L. Peluso and Michael Watts (eds.), Violent environments (Cornell University Press 2001), 189-212.

17 Ernest \& Young. "Deepwater oil and gas. BP's expertise and technology are helping to extract deepwater oil and gas safely and efficiently" (2014). British Petroleum < http://www.bp.com/en/global/corporate/sustainability/theenergy-future/deepwater-oil-and-gas.html> accessed 4 September 2015. 
domesticate them. Its exploitation is then by itself difficult, dangerous, and contaminant given the nature of the raw material.

The social consequences of oil extraction have to be added to these practical and intrinsic issues. Michael Watts has pointed out that the problems and crises related to oil are not predominantly related to its eventual or prospective depletion, with its suite of possible economic and financial consequences on the markets. The most dramatic crises are engendered by the fights for the economic benefits of oil exploitation among the stakeholders concerned and by the socio-ecological price of the production and use of this raw material. ${ }^{18}$ Oil crises are then more significantly local (meaning micro-regional), where the social and environmental effects are heavy, than national and global, where the changing price of oil only indirectly affects local communities, daily submitted to environmental degradation of reduced livelihood opportunities. Michael Watts has documented these dynamics in the Niger Delta, in Nigeria. Hisanalyses, published in 2009, are still valuable and relevant in the Nigerian context in 2016 and even more dramaticin the light of the implications of oil price slide, as the economic benefits of oil could be reduced. ${ }^{19}$

On the continental and global scales, the decline in world crude oil price certainly produces worries. Economic and financial consequences and political destabilization could be engendered by the decreasing price of oil in Africa. These risks and possible negative implications are documented and measured for African states by Damina Advisors, ${ }^{20}$ using a commodity price collapse instability risk rating. Given that 20 African countries were oil producers in 2014 and considering the key role that oil production plays in most of these economies, after the

18 Michael Watts. "Petro-violence: Community, Extraction, and Political Ecology of a Mythic Commodity" in Nancy L. Peluso and Michael Watts (eds), Violent environments (Cornell University Press 2001), 189-212; Michael Watts, "Oil, Development, and the Politics of the Bottom Billion" (2009) Macalester International, 24(11) <http://digitalcommons.macalester.edu/cgi/ viewcontent.cgi? article $=1233 \&$ context $=$ macintl $>$ accessed 4 September 2015 .

19 Michael Watts. "Oil, Development, and the Politics of the Bottom Billion" (2009) Macalester International, 24(11) < http://digitalcommons.macalester.edu/cgi/ viewcontent.cgi article $=1233 \&$ context $=$ macintl $>$ accessed 4 September 2015 .

20 Damina Advisors. "Collapsing commodity prices could trigger an African Spring" (2015) Damina Advisors <http://www.daminaadvisors.com/admin/ documents/DaMina\%20Commodity\%20Price\%20Collapse $\% 20$ and $\% 20$ Africa.pdf $>$ accessed 4 September 42015. 
Arab Spring, an African Spring could set the continent on fire, starting from countries with very high and high economic risks and with unstable political contexts (like Libya, South Sudan, Central African Republic, Democratic Republic of Congo, Chad, and the Republic of Congo) and expanding to 40 other African countries with a medium level of risk. ${ }^{21}$ It is a continental risk.

The extractive geography of oil is also changing on a global scale. The output of traditional producer countries decreases, while other countries are becoming prominent in the sector. If in fact, oil production increased in absolute terms at the global level from 1994 to 2014, things are bound to be more complex at the national level. New and improved oil technologies explain at least partially the growing production in absolute terms. Oil can be extracted faster than was possible in the past. That said, some of these recent technological advancements, such as hydraulic fracturing, are controversial. They use chemical products which pollute the environment to a high degree, thus accelerating climate change. ${ }^{22}$

Beyond technological factors, political and geopolitical factors play an important role at the regional and national level. Saudi Arabian production of crude oil remains stable during the same period, while Russian output has been rising steadily since 2009: it is nevertheless light or ultra light oil, more volatile compared to crude oil, so the quality and typology of oil available in the markets is changing. Canadian and Chinese productions have also increased, while that of Iran has declined since $2011 .{ }^{23}$ According to estimations for 2014, Russia is the first global producer with more than 10 million barrels per day; the United States is ranked third. Among the first 10 global oil producers, only three are Gulf Cooperation Council (GCC) countries. These are Saudi Arabia, United Arab Emirates, and Kuwait, ranking second, eighth, and ninth, respectively, at the global level. ${ }^{24}$

21 CIA (Central Intelligence Agency), The World Factbook 2013-2014 (CIA, 2014).

22 Lux Research, Evaluating New EOR Technologies in Oil Industry Mega-projects (Lux Research 2013).

23 Gail Tverberg "World Oil Production at 3/31/2014. Where Are We Headed?" (2014) oilprice.com < http://oilprice.com/Energy/Crude-Oil/World-OilProduction-at-3312014Where-are-We-Headed.html > accessed 17 August 2015.

24 CIA (Central Intelligence Agency), The World Factbook 2013-2014 (CIA 2014). 
In the geographies of oil, contemporary geopolitical shifts are also confirmed by the changing role of the Organization of the Petroleum Exporting Countries (OPEC), which accounts for four African member countries (Algeria, Angola, Libya, and Nigeria). Growing production in non-OPEC countries (especially the United States) and other geopolitical factors (including the slight easing of sanctions against Iran since 2014) make the OPEC henceforth unable to set global oil prices. ${ }^{25}$

Nigeria remained the largest African producer in 2015, but the crises in Libya and Egypt and the uncertainties on the future of the Democratic Republic of Congo (DRC) may change the African landscape in the future. Libya and Egypt, despite their limited production by global standards, could destabilize the entire Maghreb (where Algeria is a sizeable producer) with consequences in sub-Saharan Africa as well as in the rest of the Arab world. Political instability in the DRC would also affect Central Africa, through its relationships with the neighbouring countries and far beyond the entire continent. The DRC is, in fact, a member state of the Common Market for Eastern and Southern Africa (COMESA) and of the Economic Community of Central African States (ECCAS). Plus, internal instability or breakdown in DRC would affect its relations with neighbouring Uganda and Angola, both oil producing countries. Nigerian issues relating to the management of oil revenues, corruption, and insecurity could also have an impact on the continental geography of oil and furthermore on the global oil industry.

Figure 1, an infography by Ernest \& Young, shows how the production of oil and gas in Africa is changing on the continental, regional, and local levels: in absolute terms, revenues have doubled in a decade, following the reforms, and consequently a better and more transparent management. At the regional level, key producers are emerging in East Africa (Ethiopia, Kenya, Mozambique, Uganda, and Tanzania). At the micro level, the presence of various types of deposits (deep sea, inland, and offshore) has to be emphasized, as well as the creation of a continuous area of oil exploitation in West Africa between Senegal and Angola, along the Gulf of Guinea. This coastline, where oil wells and platforms are next to each other across national borders, raises the need for a fluid and multiscalar governance, harmonizing

25 Ante Batovic, "OPEC loosing its ability to set global oil prices" (2015) Global Risk Insights < http://globalriskinsights.com/2015/06/opec-losing-its-ability-to-setglobal-oil-prices/> accessed 17 August 2015. 
and concerting oil policies and actions among producers in the Gulf of Guinea. This multiscalar spatial justice would avoid or reduce the advent of conflicts on various scales.

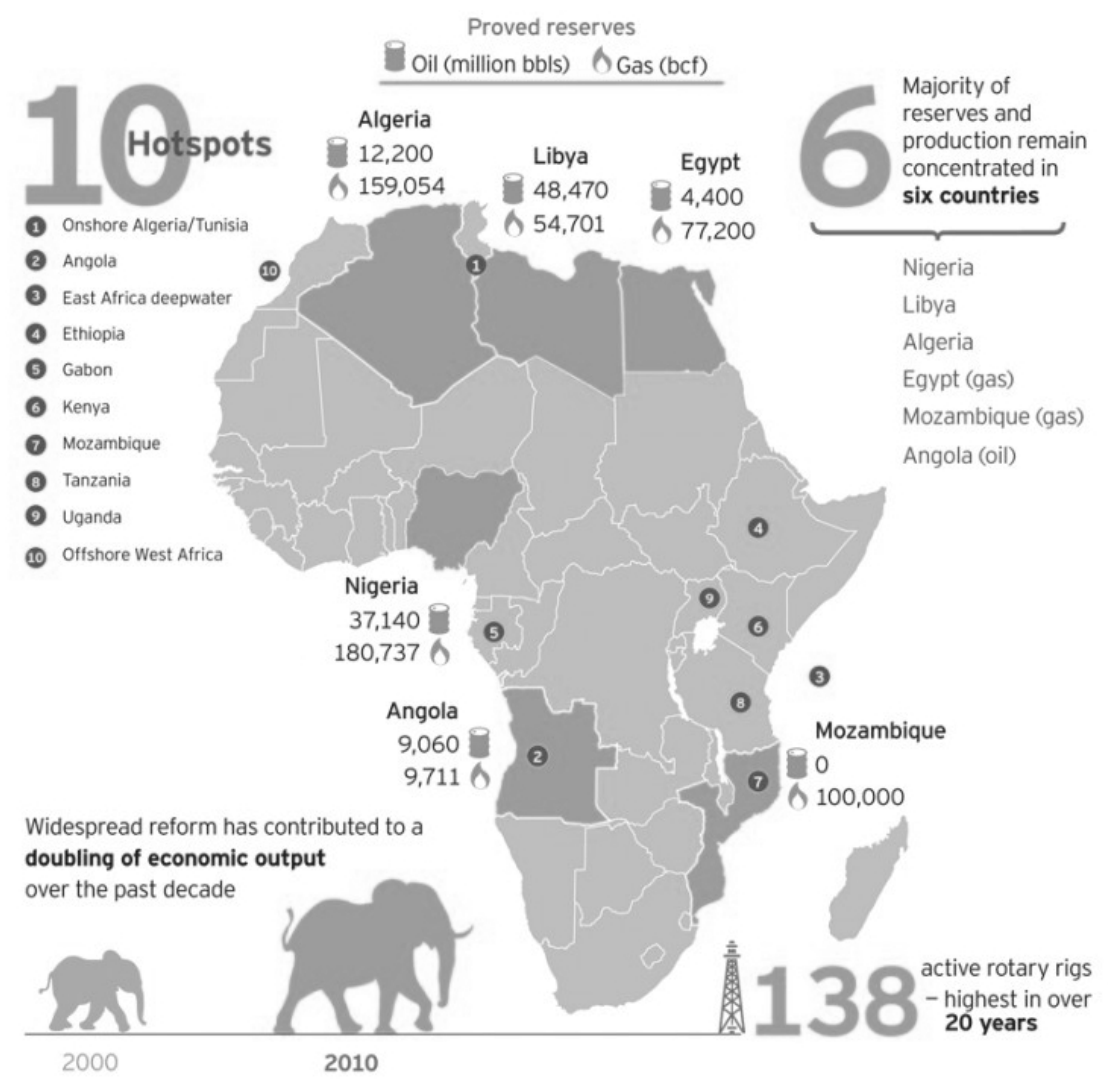

Figure 1. Oil and Gas in Africa: Sources of Sustainable Growth?

Source: Ernest and Young Report, ey.com/oilandgas

At the regional level, Figure 2 shows the networked geography of pipelines, due to the need to transport oil and gas. These networks physically translate in the landscape, commercial agreements and international relations between states, as well as interests of private actors participating to these works and the complex mechanisms to finance and realize them. The Tanzanian gas pipeline from Twara to Dar es Salaam is, for example, financed by a Chinese loan as well as by grants from the African Development Bank (AfDB) and the World Bank. 
Whereas the cooperation between neighbouring countries still seems challenging, with a consequent waste of financial resources and efforts, it has also caused local protests and conflicts, as documented by the Environmental Justice Atlas. ${ }^{26}$ Tanzania is also involved in the possible construction of a crude oil export pipeline from Uganda. The two countries did sign an agreement in 2015 to study this possibility, while the Ugandan government is also considering options through Kenya. Toyota Tsusho, Total, Chinal National Offshore Oil Corporation (CNOOC), Tullow, and the Tanzania Petroleum Development Corporation are among the stakeholders involved or trying to direct the project along the lines of their interests. ${ }^{27}$

The geopolitics of pipelines revolves around dialogues and conflicts between stakeholders to manage the pipelines. It includes agreements among countries and initiatives from the private sector and civil society. It has to deal with geological constraints, state interests, and negotiations between stakeholders. Thus, the exchanges between Ethiopia and South Sudan aim at building a pipeline connecting Djibouti to South Sudan, through a wide and rugged landscape of swamps and mountains in Ethiopia, to exclude Kenya willingly from the project. Oil and gas pipelines are spatial networks, confirming that experiences of multiscalar and fluid governance exist. Their challenges are related to their international dimension and to the interactions between stakeholders with often, incompatible interests and goals. They nevertheless offer the advantage to transform spaces and possibly improve the governance of oil and gas through dialogues involving diverse stakeholders and a form of networked justice.

At the local level, the geography of oil is neither spatial nor territorial (as it is the case for other resources, as land for example): it is a networked geography. These spatial networks are made of hubs of oil and gas wells, where the high concentration of oil and gas extracted in isolated holes makes models of territorial control inappropriate. This networked distribution of wells increase the conflict potential of places of oil and gas extraction, where economic, financial, and political interests are numerous. The power of control over these places does

26 <https://ejatlas.org/conflict/mtwara-dar-es-salaam-gas-pipeline>

27 Jeff Mbanga. "Tanzanian route throws race for Uganda's oil pipeline wide open" (2015) The Observer October 14 <http://www.observer.ug/business/38business/40422-tanzanian-route-throws-race-for-uganda-s-oil-pipeline-wideopen $>$ accessed 17 August 2015. 
not come from a form of territorial administration. This explains the incapacity of states to control oil and gas wells fully. The technical extractive expertise of multinational companies gives them an unbalanced power, often attempting to bypass state power. The local level is where government pressure, corruption, local uprising, and social conflicts express comparative advantages, attributes, and capacities, together with the power struggles associated with these uneven distributions.

Increasing the technical expertise of African oil companies would reduce the competitive advantage of foreign multinationals and their dangerous attempts to circumvent state control on oil exploitations, even through corrupt practices. Social transactions (compromises and agreements with different stakeholders, including local populations) are also needed to minimize conflicts: local content policies are useful frameworks to encourage these mechanisms of collaboration. ${ }^{28}$ The conflicts, vulnerability, and risks related to oil exploitation also explain price volatility, engendered by the real or imaginary fear that there

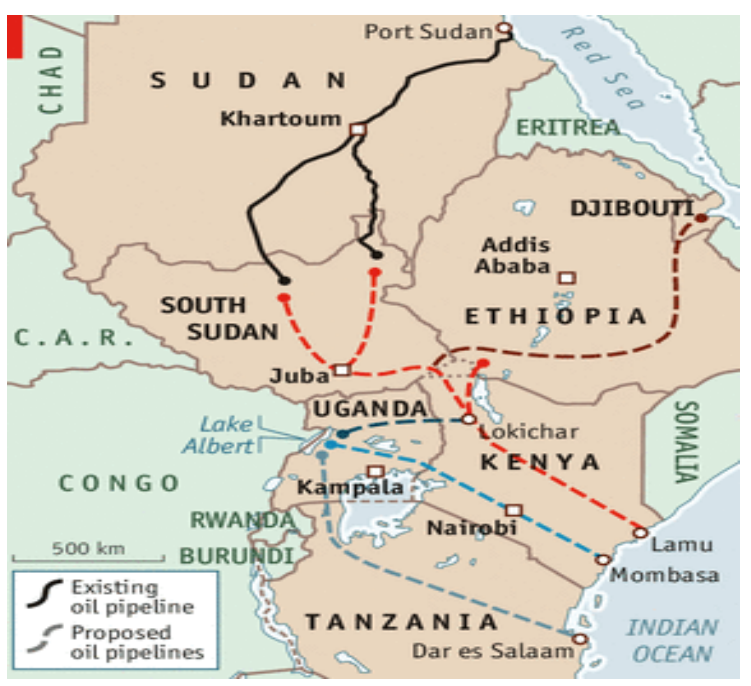

Figure 2. Existing and proposed oil pipelines

Source: http://www.economist.com/news/middle-east-and-africa/21578402east-africa-danger-throwing-away-part-its-new-found-oil

28 Silvana Tordo, Michael Warner, Osmel E. Manzano and Yahya Anouti, Local Content Policies in the Oil and Gas Sector (World Bank Publications, 2013). 
could be a shortfall of significant sources of supply, as when Nigeria stopped its oil production from 2006 to 2009. ${ }^{29}$

Therefore, given that the geography of oil and its specific discontinuous modes of production are networked, as documented above, the next section focuses on a different form of governance, adapted to these peculiar needs, necessary to prevent, manage and reduce the conflicts related to oil production, transport, and commerce. Territorial governance (or geo-governance), as they are normally theorized in geography for continuous dynamics over spaces, does not really fit with the networked realities.

\section{TERRITORIAL GOVERNANCE: A STARTING POINT, BUT AN INSUFFICIENT FRAMEWORK}

Territorial governance is a useful concept in political and economic geography, but also in urban and regional planning, as it breaks down the modalities of government of territories and spaces, underlining the interrelations between different kinds of stakeholders (public, private, international organizations, civil society, etc.), their specific relations with spaces, their goals, and motivations. Territorial governance organizes transformative action on spaces and the coordination among the stakeholders allowing it. As already demonstrated, ${ }^{30}$ territorial governance may be practically analysed through three dimensions by considering: the territorial or spatial layout where the action takes place; the existing policies related to the specific proposed action; and in the end the actions themselves (experiences, projects, and programmes). Territorial governance decomposes the process of change, its assumptions, its implementation, and consequences: it is an operational tool that geographers and planners can use to evaluate these dynamics and their results.

Territorial governance is also called geo-governance by some

29 Richard Peet, Paul Robbins and Michael Watts (eds.), Global Political Ecology (Routledge, 2010).

30 Simin Davoudi, Neil Evans, Francesca Governa and Marco Santangelo, "Territorial Governance in the Making. Approaches, Methodologies, Practices" (2008), Boletin de la A.G.E.N. 46, 33-52. 
authors, underlining the shared decision-making among stakeholders. ${ }^{31}$ Geo-governance has an intrinsic ecological dimension, in line with sustainable development theories. It is certainly also relevant for issues related to oil and gas, as their effective governance has to take into account the environmental concerns related to these resources.

Much of the literature on urban governance focuses on European and other developed countries in which territorial governance is related to urban transformation, planning, and projects, of local development. ${ }^{32}$ Local development is nowadays also studied in developing countries, including in African contexts: in these cases, governance becomes a tool of development, encompassing the local dimension, to turn to multiscalar approaches. ${ }^{33}$ Territorial governance may, in fact, be used to evaluate decentralization dynamics in which the vertical coordination between the state and international funders intersects and is added to the horizontal coordination among non-governmental organizations (NGOs) and a variety of local stakeholders. Fabienne Leloup, Laurence Moyart and Bernard Pecqueur emphasize that the state is driven "from the bottom up" (par le bas) by NGOs, with a strategic role on the field, as vectors of good governance.

This article adds that, in developing countries, the state is also overtaken from the top by international stakeholders, as well as by international, regional, and global actors, through logics of development and structural transformation. Thus, local development, even if eventually targeting a local space which does not necessarily mean reduced size, is certainly a multiscalar dynamic, encompassing the local level. Transformations at the local level also impact other levels: these changes induce reshuffling, rehierarchization, restructuring, and multiple other possible effects, including actors' changing level of action.

Notwithstanding, spatial logics of overrunning of the state (modes and forces transforming spaces that encompass state power), which

31 Nathalie Dubus, Cécile Helle and Michelle Masson-Vincent, "De la gouvernance à la géogouvernance: de nouveaux outils pour la démocratie LOCALE renouvelée" (2010) L'Espace politique 10:1 <https://espacepolitique.revues. org/1574> accessed 5 August 2015.

32 Patrick Le Galès, "Du gouvernement des villes à la gouvernance urbaine" (1995) Revue française de sciences politiques 45(1), 57-95.

33 Fabienne Leloup, Laurence Moyart et Bernard Pecqueur, "La gouvernance territoriale comme nouveau mode de coordination territoriale ?"(2005) Géographie, économie et société 7(4), 321-332. 
may be easily identified in developing countries, are constant characteristics of globalization and its plural, complex and intrinsically multiscalar dynamics. As Fabienne Leloup, Laurence Moyart, and Bernard Pecqueur indicated using examples of industrial and commercial clusters in West Africa, in Africa as elsewhere nowadays the state is in charge of ensuring the redistribution of revenues at various levels (through effective decentralization and an efficient management of its various territories) and a coordination of development actors from the international to the local level. ${ }^{34}$

The fundamental role of small and medium enterprises (SMEs) in African economies, related to industrialization (including oil refining industries), to which the three authors refer, is to produce economic, commercial, and spatial dynamics overrunning the state. In a global world, industrialization of African countries and markets bypass state capacities and control. SMEs also have an important role in line with the contemporary investigations on financing for development for the post-2015 agenda. A study made by the United Nations Sustainable Development Solution Network (UNSDSN) shows that official development assistance will continue to have a prominent role in the post-2015 development agenda, but that innovation will be key. ${ }^{35}$ Important contributions will come from sovereign wealth funds and other new financial tools to finance SMEs, especially those with sizeable impacts at various levels of development, among which certainly are SMEs working in the extractive sector.

\section{TOWARDS A FLUID, MULTISCALAR, AND NETWORKED GOVERNANCE OF OIL AND EXTRACTIVES IN AFRICA}

The multiscalar geography of oil presented above demonstrates that its governance may not be reduced to a classic territorial governance and to the play of forces between different stakeholders on a given territory, because a continuous and coherent territory of extraction and transformation does not exist, even if mechanisms of ownership are created by the socio-economic issues that the resource engenders.

34 Ibid.

35 Guido Schmidt-Traub and Jeffrey D. Sachs, "The Roles of Public and Private Development Finance" (2015), UNSDSN Issue Brief UNSDSN. 
Oil is, in fact, a fugitive and migrating underground resource, therefore difficult to capture. This explains the need for setting up in some contexts models of governance as property among oil-exploiting neighbours whose contiguity makes their respective activities dependent on one another. It is what happens nowadays in the Gulf of Guinea for the marine exploitation, knowing that some oil companies are operating across territorial borders (e.g. Noble Energy has core operations in Equatorial Guinea and Cameroon, but is exploring new ventures in Sierra Leone and Gabon).

This model of governance as property, dangerous because of its conflictual position, may be pushed to the extreme where states adopt nationalistic approaches, such as happened in some cases in Africa, through the fear of losing control and precedence on the exploitation of the resource. Resource nationalisms, therefore, can have various forms, even on the African continent: ${ }^{36}$ ready examples being Nigerian nationalism in the 1980s and the more recent one in Mozambique. Beyond the differences in the mechanisms of nationalisms, national companies (e.g. Ghana National Petroleum Corporation) make the landscape of stakeholders involved in oil extraction even more complex, even though they open new paths of governance for the future. Oil companies from the West or from emerging countries (like China) cannot ignore their presence and action, forcing them to set up a dialogue with local multinationals.

In that sense, oil is not a cooperative resource: ${ }^{37}$ it is elusive and requires advanced scientific and technical knowledge, important investments, and adequate legal systems. These numerous prerequisites make the oil extraction business an elitist venture, because the number of competitive firms in this domain is relatively reduced. To maintain a high operational level a firm needs to secure constant and long-term access to large exploitations, which explains the aggressive and

36 Stefan Andreasson, "Varieties of Resource Nationalism in Sub-Saharan Africa's Energy and Minerals Markets" (2015) < http://works.bepress.com/cgi/ viewcontent.cgi article $=1023 \&$ context $=$ stefan_andreasson $>$ accessed 19 August 2015.

37 Karen Bakker, An Uncooperative Commodity: Privatizing Water in England and Wales (Oxford University Press 2004); Karen Bakker and Gavin Bridge, "Material Worlds? Resource Geographies and the 'Matter of Nature"' (2006) Progress in Human Geography 30(1), 1-23. 
conflictual governance to conquer new unexploited areas. ${ }^{38}$ Oil companies fight against one another to discover and control oil exploitations or pipelines. They also aggressively defend their interests against local communities, civil society, and African states. Shell has had decades of fight in Nigeria against environmental and social accusations. Soco International similarly had a short but intense conflict for exploration rights in the Virunga National Park in the Democratic Republic of Congo. The governance adopted by states and the different types that oil companies set in place are difficult to conciliate: the heterogeneity and incompatibility between these two regimes of governance clarify the apparent myopia of international oil companies, seeming to ignore that the interests of producing countries increasingly condition decisions on production rates. ${ }^{39}$

Furthermore, the complex landscape of multiscalar oil governance cannot be reduced to agreements between states and to the role of oil companies: other stakeholders make this governance more multifaceted and complex. Additionally, extractive dynamics require taking into account the equally complex and multiscalar environmental governance of oil, ${ }^{40}$ encompassing local issues of pollution or occasional ecological catastrophes, produced by a specific incident. The macro-regions in which atmosphere pollution related to oil may be traced define the geography of environmental damages of oil..$^{41}$ There is then not only an environmental and social cost of oil production and refining, but also a specific governance related to the interaction of various stakeholders (citizens, NGOs, associations, etc.), involved in the environmental protection of areas damaged by extraction.

For these reasons, oil governance must be fluid, adapting to oil some forms of governance used by scientists and practitioners to analyse

38 Richard Peet, Paul Robbins and Michael Watts (eds.), Global political ecology (Routledge, 2010).

39 Michael Watts, "Petro-violence: Community, Extraction, and Political Ecology of a Mythic Commodity" in Nancy L. Peluso and Michael Watts (eds), Violent environments (Cornell University Press 2001), 189-212.

40 Kobena T. Hanson, Cristina D'Alessandro and Francis Owusu (eds), Managing Africa's Natural Resources. Capacities for Development (Palgrave 2014).

41 Benjamin D. Duval, "Deepwater Horizon spill made a city's worth of air pollution" (2012) EarthSky < http://earthsky.org/earth/deepwater-horizon-oil-spillmade-a-citys-worth-of-air-pollution> accessed 19 August 2015. 
planning of metropolises ${ }^{42}$ or water management ${ }^{43}$ or some forms of micro-regionalisms in emerging regions. ${ }^{44}$ These recent and heterogeneous approaches fit well with the specific characteristics of oil governance. Daniel Kübler's analysis of Swiss cities emphasizes the opposition between bureaucratic governance (that could be defined as territorial, because the jurisdiction of an administration is related to a given territory) and a fluid governance "based on conglomerates of heterogeneous stakeholders", in accordance with new regionalisms. ${ }^{45}$

According to Katsushiro Sasuga, fluid governance is networked, as it links the concepts of "governance" and "network" and is specifically used to analyse the interactions between public administrations and private sector actors, as well as relations inside a multinational or between multinationals. ${ }^{46}$ The micro-regions to which Sasuga refers are explicitly intra-state spaces or trans-boundary areas; the specific governance required in these settings is associated to economic dynamics: multinationals, local administrations, and the state are part of it.

The southern Chinese region is the example Sasuga used to illustrate its definition of networked governance. This micro-regionalism focuses on what could be called accidents of location, meaning the consequences of location, as the author says, as well as the consequences of state choices and decisions. The region is then in the reality a space of networked relations, as it is the case among multinationals in Hong Kong, where three levels may be identified: intra-multinational, intermultinational, and extra-multinational in the Association of Southeast Asian Nations (ASEAN) region. Sasuga adds "these production networks are increasingly linked to local governments and policy networks of all kinds in the remarkably fluid multilevel governance arrangements that

42 Daniel Kübler. La métropole et le citoyen. Les agglomérations urbaines en Suisse vues par leurs habitants (EPFL Press, 2005).

43 Vasna Ramasar, Fluid Governance. Scalar Politics in the South African Waterscape (Lund University Publications, 2014).

44 Katsushiro Sasuga. Microregionalism and Governance in East Asia (Routledge, 2004).

45 Daniel Kübler. La métropole et le citoyen. Les agglomérations urbaines en Suisse vues par leurs habitants (EPFL Press 2005), 117; Timothy Shaw, John A. Grant and Scarlett Cornelissen (eds), The Ashgate Research Companion to Regionalisms (Ashgate, 2012).

46 Katsushiro Sasuga. Microregionalism and Governance in East Asia (Routledge, 2004), 11. 
are emerging. Intermediate associations, such as local business associations, also play a vitally important networking role in linking state actors and firms". ${ }^{47}$ The regime of multiscalar, fluid, and networked governance encompasses the government of the nation-state, because decision-making networks on which it relies bypass national borders and the administrative jurisdictions of these territories, including informal, non-governmental, and transnational mechanisms. This governance approach attracts the attention on efficient mechanisms of coordination of rules and actions of various stakeholders.

This governance approach is eminently political (as based on power interactions and leadership), even if it is not limited to state functioning. It confirms that the separation between the national and international levels loses the effectiveness that it had in the past, because stakeholders interact formally and/or informally at various levels, using multiscalar decision-making networks and policies. ${ }^{48}$ Given the traditionally centralized Chinese political system countering this transformation, Sasuga's case study explores the challenges of implementation of such pluralistic and multiscalar system in southern China. This example also facilitates a comparison with developing countries, in which institutional capacity gaps make the creation of flexible governance mechanisms more difficult, while fostering informal and parallel dynamics of counter-governance (such as corruption).

The study on water governance in South Africa by Vasna Ramasar ${ }^{49}$ underlines not only the political and economic aspects and conflictual issues related to multiscalar water management, but also that this governance is intrinsically environmental, because ecological, economic, and political factors shape the hydrosocial landscape of water access and use, through justice and equity.

The governance of oil and extractive resources in general is multiscalar, networked, and fluid, but also environmental. It aims at a less conflictual and more effective coordination of stakeholders in formal and informal contexts of oil extraction and processing. In Africa, these dynamics take place in challenging contexts, although situations greatly vary from one country to another, with specific gaps and deficits at

47 Katsushiro Sasuga. Microregionalism and Governance in East Asia (Routledge, 2004), 30.

48 Ibid: $32-33$.

49 Vasna Ramasar. Fluid Governance. Scalar Politics in the South African Waterscape (Lund University Publications, 2014). 
various levels. To improve interactions through this type of governance, a form of geographical justice is key.

\section{FROM SPATIAL JUSTICE TO NETWORKED JUSTICE}

This dimension of governance aims to promote a flexible management of resources, paying more attention to the various stakeholders, their goals, and to the damages that oil exploitation may do to different social groups and at various levels, conceptualized as spatial justice, used for instance for territorial (and more specifically urban) policies. Spatial justice comes from the attempt to find the fairest scale on the part of the government for social phenomena, if any. ${ }^{50}$ Spatial justice offers then a framework to deal with injustices and inequalities related to oil extraction, to advocate for a better redistribution of powers and enhance public participation, even if participatory democracy is often only a rhetoric used in discourses justifying territorial transformations made by public policies.

Spatial justice also reminds one of the existence of authoritarian spaces, characterized by a peculiar practice of power. ${ }^{51}$ If in many situations (including a number of contexts of exploitation of extractives) good governance and democratic, participatory, and procedural justice are not in place, in these contexts and in relation to these dynamics one may notice peculiar forms of authority and of transmission of authority (through financial or technological capacities, via the access to medias and consequently by the capacity to produce widely accessible information, etc.). In this case, authority is not related to a given territory, but to networked dynamics, places and interactions between stakeholders.

Following Henry Lefebvre ${ }^{52}$ and Alain Reynaud ${ }^{53}$ the spatial justice framework has been used in a myriad of contexts to denounce spatial inequalities (access to water, to the land, to education, to health

50 Philippe Gervais-Lambony and Frédéric Dufaux. "Justice...spatiale !" (2009) Annales de Géographie, 665-666, 3-15.

51 Sabine Planel, “Espaces autoritaires, espaces (in)justes ?"(2015) Spatial Justice 8 July <http://www.jssj.org/article/espaces-autoritaires-espaces-injustes/> accessed 21 August 2015.

52 Henry Levebvre, Le droit à la ville (Anthropos, 1968).

53 Alain Raynaud, Société, espace et justice (Presses Universitaires de France, 1981). 
services, etc.) and spatial segregation (in urban contexts for instance). Spatial inequalities may be considered as spatial injustices; analyses may consequently suggest an alternative organization of the space with fair access to resources and to the benefits that they engender. This also applies to the geographies of extractives and to the multiscalar geographies of inequalities and the injustices that they cause. The governance model presented above may specifically be a strategy to detect and reduce these injustices in a multiscalar and coordinated way, and on a longer term.

Applying the spatial justice framework to the governance of oil and extractive resources, the geographical justice in these instances is more a multiscalar, fluid, and networked justice, with discontinuous features. Governance of extractive resources thus produces offshore network places, to echo Sidaway on offshore spaces. ${ }^{54}$ James Sidaway demonstrates the existence of offshore spaces with graduated sovereignty, described as a multitude of different modes of government for various social groups, depending on their relationship with global markets, because each group has specific regulatory compromises and modalities of control, in relation to a peculiar space of production. This is exactly what happens with extractive resources, because oil and gas create peculiar social and spatial networks, with specific rules and modalities of interaction with global markets, not applying to the population directly or indirectly (through pollution for example) concerned by its extraction.

Sidaway's paper refers to post-development, in line with postcolonial studies and investigations on imperialism, to criticize and contrast epistemologies of development, their categories, discourses, assumptions, and methods; ${ }^{55}$ the negative effects of which have been proved in Africa. ${ }^{56} \mathrm{~A}$ call for fluid and multiscalar governance framework for extractive resources in Africa, even if differently, goes in the same

54 James D. Sidaway, "Spaces of postdevelopment" (2007) Progress in Human Geography 31(3), 345-361.

55 Claire Mercer, Giles Mohan and Marcus Power, "Towards a critical political geography of African development" (2003), Geoforum 34, 419-436.

56 Cristina D'Alessandro-Scarpari, Géographes en brousse. Un métissage spatial entre discours et pratiques (LHarmattan, 2005); Estienne Rodary, "Développer la conservation ou conserver le développement? Quelques considérations historiques sur les deux termes et les moyens d'en sortir" (2008) Mondes en Développement 36(141), 81-92. 
direction, as it calls for greater ownership of resources by African stakeholders and better mechanisms to enforce justice based spaces and the exploitation of resources.

\section{TOWARDS A BETTER GOVERNANCE OF EXTRACTIVE RESOURCES IN AFRICA}

The argument presented in this article is that natural resource governance, specifically for oil and gas, needs to be fluid, networked, and multisclar. This indicates that governance is a set of coordinated actions among stakeholders and harmonized policies at the various levels (local, micro-regional, national, macro-regional, continental, and global). This requires flexibility to adapt and fluidity to avoid considering the spaces and networks involved as fixed and limited territories. If the relationships between the government and multinational corporations are important for the extractive sector and its entire value chain, multiscalar considerations bring in local governments, local associations, and international civil society platforms among others.

The governance of extractive resources has to take into account the entire value chain of these raw materials, giving the right place to the extraction process without being limited to it. Concepts like (fluid and multiscalar) governance and (networked) justice may help to consider these issues not only from a scientific point of view, but also with a practical goal. A better understanding through analysis helps to set in place less conflictual governance mechanisms, paying more attention to the needs and perspectives of the various stakeholders involved, to prevent conflicts, injustices, and inequalities, supporting economic transformation and development of African countries. Development being understood as enhanced conditions of life for African populations, reduced poverty levels, while ensuring that local communities benefit in some way from oil revenues, not only suffering for environmental degradation.

In developing countries, multiscalar, networked, and fluid governance of extractive resources requires building the necessary capacities: mainly but not only institutional, but also technical, financial, scientific, policy, and implementation capacities. This applies equally to African contexts, where the multiscalar approach is specifically crucial: regional governance mechanisms for extractive resources are still deficient and difficult to implement, although tremendous progress 
has been made through the Africa Mining Vision (AMV), the roadmap for implementing a multiscalar mining policy (including fossil fuels like oil and gas)s pecifically adapted to African contexts and needs. The regional and continental scales are of particular importance in Africa, but the national level, with specific policies and contexts is also a crucial starting point, to which the AMV is devoting a particular attention for its progressive implementation.

Similar to what has been said for oil and gas, an analogous approach could be used for other natural resources. Possibly intersecting various value chains of different resources, interfering with the same spaces at different levels (of which the national level seems to remain preeminent at least on the short term, given the consequences of national policies on their exploitation), in different places or in certain situations (notably the implementation of coordinated policies).

Governance of natural resources emphasizes the importance and complexity of the geographical dimension of these dynamics, but it also underlines the commitment to some kind of geographical justice (spatial or reticular), arising from these situations. Geographers, together with other scientists, with their expertise can help solve or avoid conflicts related to natural resources: the gap between academic and policy research is being reduced, but remains, especially in Africa. 